\title{
Unsur Intrinsik Cerpen dalam Portal Berita Online serta Relevansinya sebagai Materi Ajar Sastra di SMA
}

\author{
Devi Damayanti*, Sahlan Mujtaba, Muhammad Januar Ibnu Adham \\ Universitas Singaperbangsa Karawang, Indonesia \\ *Coresponding Author: 1710631080006@student.unsika.ac.id
}

Article History:

Received 2021-12-16

Revised 2022-01-25

Accepted 2022-02-09

DOI:

10.31949/educatio.v8i1.1813

\begin{abstract}
One of the literary learning activities in schools is in the form of analyzing intrinsic elements. Studying the intrinsic elements contained in literary works can belp students in interpreting life. This research was conducted with the aim of describing the intrinsic elements contained in the five short stories of the online news portal Jawa Pos in the November and December 2020 editions and seeing their relevance as literature learning materials in high school. The approach used in this research is descriptive analytical approach using qualitative methods. The data source used is the script of the five short stories uploaded in the Jawa Pos online news portal. Through this manuscript, data were collected and qualified. The conclusions of this study are: 1) The intrinsic elements contained in the five short stories of the online news portal Jawa Pos in the November and December 2020 editions include themes, characterizations, settings, and points of view, and 2) The five short stories in the online news portal Jawa Pos November and December editions. 2020 is relevant to be used as a reference in the delivery of teaching materials in schools.
\end{abstract}

Keywords: short story; teaching materials; intrinsic element

\begin{abstract}
Abstrak
Salah satu kegiatan pembelajaran sastra di sekolah yaitu berupa kegiatan menganalisis unsur intrinsik. Mengkaji unsur intrinsik yang terkandung di dalam karya sastra dapat membantu peserta didik dalam memaknai kehidupan Penelitian ini dilakukan dengan tujuan mendeskripsikan unsur intrinsik yang terkandung pada kelima cerpen portal berita online Jawa Pos edisi November dan Desember 2020 serta melihat relevansinya sebagai materi pembelajaran sastra di SMA. Pendekatan yang digunakan dalam penelitian ini ialah pendekatan deskriptif analitik dengan menggunakan metode kualitatif. Sumber data yang digunakan berupa naskah kelima cerpen yang diunggah dalam portal berita online Jawa Pos. Melalui naskah tersebut data-data dikumpulkan dan dikualifikasi. Simpulan penelitian ini ialah: 1) Unsur intrinsik yang terkandung dalam kelima cerpen portal berita online Jawa Pos edisi November dan Desember 2020 meliputi tema, penokohan, latar, dan sudut pandang, dan 2) Kelima cerpen dalam portal berita online Jawa Pos edisi November dan Desember 2020 relevan dijadikan sebagai rujukan dalam kegiatan penyampaian materi ajar di sekolah.
\end{abstract}

Kata Kunci: cerpen; materi ajar; unsur intrinsik

\section{PENDAHULUAN}

Perkembangan teknologi dalam kehidupan manusia menjadikan karya sastra kian mudah ditemukan dalam media digital. Bahkan lebih jauh lagi efek yang diberikan dari kemajuan teknologi bagi karya sastra yaitu berupa peralihan penggunaan kertas sebagai media tulis sastra. Perubahan yang terjadi akibat kemajuan teknologi dalam ranah sastra tentu menjadi hal yang patut disyukuri. Namun sangat disayangkan bahwa kemudahan akses yang ditawarkan sastra digital tidak mengubah kenyataan bahwa masyarakat di Indonesia masih cukup malas dalam kegiatan literasi. Kenyataan tersebut tentu sangat menyedihkan, mengingat kegiatan literasi membawa cukup banyak manfaat bagi para pembaca di antaranya meningkatkan keterampilan berbahasa dan kemampuan memaknai kehidupan.

Rendahnya tingkat literasi di Indonesia dibuktikan oleh data yang didapat melalui situs KOMINFO yang terbit pada Oktober 2017. Dituliskan bahwa UNESCO menyatakan pada tahun 2012 minat baca 
masyarakat di Indonesia hanya berkisar 0,001\%. Selain itu, pada Maret 2016, Central Connecticut State Univesity (CCSU) mengeluarkan hasil penelitiannya terkait jumlah minat baca di Indonesia yang masih menduduki posisi ke-60 dari 61 negara. Data-data yang dikeluarkan oleh badan lembaga tersebut menjadi bukti konkret bahwa tingkat literasi di Indonesia masih sangat jauh dari kata baik. Tingkat pemakaian ponsel yang berlebihan akhirnya menimbulkan hal-hal negatif seperti mudahnya masyarakat menjadi bahan provokasi di media sosial, sehingga menimbulkan munculnya perdebatan panas dalam kegiatan bersosial media.

Fenomena buruk dalam kegiatan bersosial media tersebut pada akhirnya dapat memberi pengaruh negatif bagi generasi muda. Mengingat sekarang ini hampir seluruh generasi muda memiliki akun media sosial dan aktif menggunakannya (Cahyono, 2016). Kurangnya pemahaman dalam merespons suatu masalah dapat menyebabkan generasi muda dengan mudah menjadi korban provokasi dalam jejaring media sosial. Oleh karenanya, pemahaman-pemahaman mengenai cara menyikapi suatu permasalahan dapat diajarkan oleh guru di sekolah. Salah satunya dengan cara mempelajari dan memperkenalkan sastra sebagai sebuah karya seni yang tak hanya bersifat fiksi. Namun juga sebagai suatu karya yang lahir dari hasil pemikiran dan pengamatan seorang pengarang atas kehidupan yang dijalaninya.

Oleh karena karya sastra berasal dari hasil pemikiran dan pengamatan seorang pengarang atas kehidupan yang dijalaninya, maka hal tersebut pula yang menjadikan karya sastra banyak memuat hal-hal terkait persoalan kehidupan (Ismayani, 2017). Kegiatan pembelajaran apresiasi sastra di sekolah dapat menciptakan kepribadian yang lebih baik dan juga pemikiran yang cerdas, terutama dalam menyikapi suatu permasalahan (Saputra, 2020). Hal tersebut dikarenakan sastra tak hanya memuat tulisan indah di dalamnya, namun juga berisi nilai-nilai kehidupan yang dapat dipelajari dengan baik. Ungkapan tersebut sejalan dengan pendapat (Gasong, 2019) yang mengatakan bahwa karya sastra mampu menghadirkan kesadaran bagi pembacanya terkait kebenaran-kebenaran hidup, dikarenakan di dalamnya terdapat pengetahuan dan pemahaman yang berkaitan dengan manusia, dunia dan kehidupannya.

Salah satu kegiatan pembelajaran sastra di sekolah yaitu berupa kegiatan menganalisis unsur intrinsik. Kegiatan tersebut termasuk ke dalam kegiatan apresiasi sastra secara langsung. Kegiatan mengapresiasi sastra seperti menganalisis unsur intrinsik yang terkandung di dalamnya dapat membantu peserta didik dalam memaknai kehidupan. Sehingga membangun karakter yang dimiliki oleh peserta didik. Unsur intrinsik merupakan sebuah unsur yang paling utama dalam membangun perwujudan cerita secara utuh (Gasong, 2019; Saputri, 2017; Sarmianti, 2017). Selain itu, Saad (Sukada 2013) membagi unsur intrinsik menjadi ke dalam empat bagian, di antaranya 1) tema, 2) penokohan, 3) latar, dan 4) pusat pengisahan. Keempat unsur tersebut yang menjadikan karya sastra memiliki karakter cerita yang kuat dan akurat, sehingga isi cerita yang disampaikan menjadi lebih hidup dan dapat tersampaikan dengan benar.

Namun sangat disayangkan, bahwa tidak semua sekolah mampu menjalankan kegiatan pembelajaran apresiasi sastra dengan baik. Salah satu faktor yang menjadikan kegiatan pembelajaran sastra di sekolah tidak berjalan efektif yaitu kurang dan tidak tersedianya sumber belajar yang memadai. Padahal kegiatan pembelajaran sastra di sekolah termasuk ke dalam pembelajaran yang juga memegang peran penting bagi pemahaman peserta didik. Namun, permasalahan berupa kurang dan tidak tersedianya sumber belajar sastra di sekolah dapat diatasi dengan pemanfaatan kemajuan teknologi. Seperti yang telah dijelaskan sebelumnya, bahwa kemajuan teknologi telah menghadirkan kemudahan dalam mencari ragam jenis karya sastra di jejaring media digital. Bahkan di saat ini pun telah banyak ditemukan aplikasi maupun situs web yang memuat berbagai macam jenis karya sastra mulai dari novel, cerpen, naskah drama, hingga puisi yang dapat dilihat dan dibaca secara bebas. Salah satunya yaitu situs web berita online Jawa Pos.

Jawa Pos sendiri merupakan salah satu media massa yang menduduki peringkat utama dalam kategori Top Daily Newspaper berdasarkan peninjauan yang dilakukan oleh Nielsen Consumer and Media View (CMV) pada Juni 2017. Peninjauan tersebut membuat Jawa Pos mendapatkan gelar sebagai salah satu media massa terbesar dengan jumlah pembaca sebanyak 842.000. Menyandang gelar sebagai media massa terbesar menjadikan Jawa Pos memiliki tingkat kredibilitas yang tinggi dari masyarakat. Portal berita online Jawa Pos menyediakan rubik bacaan sastra berupa kumpulan cerpen yang dapat diakses secara bebas dan diperbarui setiap akhir pekan. Selain itu cerpen-cerpen dalam portal berita online Jawa Pos memiliki karakteristik tersendiri seperti 
penggunaan bahasa yang mudah dipahami, ilustrasi gambar serta tema-tema cerita yang banyak berkaitan dengan isu sosial di masyarakat.

Banyak penelitian terdahulu yang melakukan analisis intrinsik pada sebuah cerpen, diantaranya penelitian yang dilakukan oleh Maryanti et al (2018) dalam cerpen "Katastropa", penelitian Nurcahyati et al(2019) dalam cerpen "Senyum Karyamin", penelitian Surbakti et al (2018) dalam Cerpen "Hening di Ujung Senja", dan penelitian Ujang terhadap Cerpen "Pengemis Dan Shalawat Badar". Dalam penelitian ini, peneliti memilih kelima cerpen portal berita online Jawa Pos edisi November dan Desember 2020 yang diharapkan dapat dijadikan referensi materi ajar sastra di kelas. Beberapa cerpen di antaranya yaitu, Seorang Ayah yang Mencemaskan Mimpinya (terbit 01 November 2020), Bibiryang Tercecer (terbit 13 Desember 2020), dan Baju Natal Buat Sang Cucu (terbit 25 Desember 2020).

Berdasarkan latar belakang tersebut, maka penelitian ini bertujuan sebagai upaya pemahaman tentang cara memaknai kehidupan melalui karya sastra. Sehingga peserta didik mampu melihat segala permasalahan dan menyikapinya dengan baik. Selain itu, penelitian ini juga diharapkan mampu menjadi solusi dalam mengatasi kurangnya sumber belajar sastra serta mampu menjadi referensi dalam materi pengajaran sastra di sekolah.

\section{METODE PENELITIAN}

Berdasarkan tujuan penelitian yang telah disampaikan, maka diketahui bahwa objek penelitian ini ialah unsur intrinsik sedangkan untuk subjek penelitiannya yaitu cerpen dalam portal berita online Jawa Pos edisi November dan Desember 2020. Dalam menganalisis unsur intrinsik cerpen ini, penulis menggunakan pendekatan kualitatif. Menurut Bogdan dan Taylor (dalam Nugrahani, 2014) mengungkapkan bahwa penelitian kualitatif adalah penelitian yang menyajikan data deskriptif berupa ucapan, tulisan, dan tindakan dari suatu hal yang telah diamati. Maka, berdasarkan pendapat tersebut, penulis berusaha menyajikan data dalam bentuk tulisan yang memuat data-data terkait analisis ketiga cerpen. Sedangkan pendekatan yang digunakan dalam penelitian ini berupa pendekatan deskriptif analitik. Pendekatan deskriptif analitik menyajikan data berupa kata dan gambar yang dideskripsikan dengan sejujur-jujurnya.

Teknik pengumpulan data yang digunakan dalam penelitian ini berupa teknik baca, simak, dan catat. Dalam teknik tersebut peneliti memulai kegiatan analisis dengan membaca subjek penelitian. Kegiatan membaca yang dimaksud mengarah pada membaca dengan cermat dengan memberi perhatian pada objek yang diteliti. Kegiatan membaca dengan cermat dan berfokus pada objek penelitian disebut sebagai kegiatan menyimak, kemudian setelahnya peneliti mencatat data-data yang ditemukan. Kegiatan membaca, menyimak, dan membaca tersebut kemudian disebut sebagai sebuah teknik baca, simak, dan catat (Ratna, 2010). Langkah-langkah yang dilakukan dalam pengumpulan data pada penelitian ini adalah: 1) Membaca dan memahami kembali ketiga cerpen dalam portal berita online Jawa Pos edisi November dan Desember 2020, 2) Menyimak dengan cermat dan berfokus pada objek penelitian yang tengah dicari, yaitu unsur intrinsik dalam cerpen, dan 3) Mencatat dan menginterpretasikan data-data yang telah ditemukan melalui proses membaca dan menyimak. Setelah data terkumpul, selanjutnya dianalisis dengan reduksi data, penyajian data dan penarikan kesimpulan.

\section{HASIL DAN PEMBAHASAN}

Penelitian ini berusaha melakukan analisis unsur intrinsik terhadap cerpen dalam portal berita online Jawa Pos edisi November 2020. Dalam menganalisis unsur intrinsik ini, penulis menggunakan pendekatan kualitatif.

1. Analisis Unsur Intrinsik

Unsur intrinsik yang dikaji dalam penelitian ini diantaranya adalah tema, tokoh, dan latar pada Cerpen "Seorang Ayah yang Mencemaskan Mimpinya" karya Hilmi Faiq

a. Tema 
Cerpen Seorang Ayah yang Mencemaskan Mimpinya mengandung tema mayor berupa kemiskinan. Tema kemiskinan dalam cerpen tersebut kembali difokuskan pada isu ketimpangan finansial dalam kegiatan pembelajaran daring di masa pandemi covid-19.

Tak punya HP tidak pernah menjadi masalah hingga pandemi korona melanda. Apalagi sejak tahun ajaran baru ketika anak-anak sekolah diharuskan belajar di rumah. Katanya, guru-guru akan bergantian datang mengajar lewat laptop atau HP. Itu aku dengar dari anak tunggalku, Soleha, yang mendengar kabar dari teman-temannya di kampung. Kami tak punya HP, jadi selalu ketinggalan info dari sekolah.

Melalui kutipan tersebut diketahui bahwa tema yang terdapat dalam cerpen berusaha menunjukkan ketimpangan kondisi pembelajaran yang terjadi pada para pelajar di masa pandemi covid.

b. Tokoh

Tokoh yang pertama adalah tokoh aku. Tokoh ini dalam cerpen Seorang Ayah yang Mencemaskan Mimpinya berperan sebagai tokoh utama dan pusat penceritaan. Tokoh aku dalam cerpen memiliki peran sebagai seorang Bapak yang memiliki anak tunggal bernama Soleha. Tokoh aku memiliki perwatakan pandai bersyukur. Berikut kutipannya.

Seingatku, sejak lahir, Soleha tak pernah meminta apa pun. Meskipun itu sekadar permen. Aku bersyukur dianugerahi anak yang begitu paham kondisi dan derita orang tuanya.

Tokoh kedua adalah satpam. Tokoh satpam berperan sebagai tokoh protagonis, selain itu tokoh satpam juga digambarkan memiliki ciri fisik yang gemuk, jangkung dan lincah. Berikut kutipannya.

Perhitunganku kurang tepat. Lincah juga satpam jangkung ini. Meski sempat terjongkok setelah aku tampar kuping kanannya, langsung bangkit.

DUH, di depan ada dua satpam lari ke arabku dengan membawa pentungan. Dua-duanya lebih gemuk dariku.

Tokoh ketiga adalah kakek Supriatna. Tokoh ini dalam cerpen digambarkan sebagai guru yang telah mengajarkan ilmu bela diri kepada tokoh aku di masa remaja. dapat dilihat bahwa Kakek Supriatna memiliki watak pemaksa, namun hal tersebut dilakukan demi kebaikan untuk tokoh aku. Berikut kutipannya.

Saat begini, aku harus berterima kasib kepada Kakek Supriatna yang dulu memaksaku belajar silat.

Tokoh keempat adalah gerombolan warga. Dalam cerita ini, tokoh gerombolan warga tidak dideskripsikan dengan jelas. Namun karakter tokoh gerombolan warga digambarkan melalui tindakan yang dilakukan. Tokoh gerombolan warga memiliki watak yang kasar dan suka main hakim sendiri. Selain itu, tokoh gerombolan warga merupakan tokoh tambahan, tokoh sederhana, dan tokoh antagonis. Berikut kutipannya.

Semua umpatan itu bersabutan bersama tendangan, pukulan, gebukan, dan ludahan mereka. Aku babkean merasa badanku melayang sebelum menghunjam ke tanah. Berkali-kali.

Tokoh kelima adalah Soleha. Tokoh Soleha digambarkan sebagai seorang putri tunggal dari tokoh aku. Di dalam cerita, perwatakan tokoh Soleha digambarkan secara analitik oleh pengarang. Soleha memiliki watak pengertian, khususnya terhadap kondisi dan derita yang dihadapi orang tuanya. Selain itu, tokoh Soleha berperan sebgai tokoh tambahan dan tokoh protagonis. Berikut kutipan terkait tokoh Soleha.

Seingatku, sejak labir, Soleha tak pernah meminta apa pun. Meskipun itu sekadar permen. Aku bersyukur dianugerahi anak yang begitu paham kondisi dan derita orang tuanya.

Konon, anak yang labir pagi hari menyukai kebersihan, lembut, ramah, dan memiliki sopan santun yang mengagumkan. Dia juga rendah hati dan mudah jatub iba.

Tokoh keenam adalah istri, tokoh ini dalam cerpen tidak memiliki peran yang begitu penting. Secara umum, tokoh istri sendiri digambarkan sebagai seorang ibu dari Soleha dan juga pasangan dari tokoh aku. Tokoh istri berperan sebagai tokoh tambahan, tokoh sederhana dan tokoh protagonis. Berikut kutipannya.

"Gimana caranya?" tanya istriku yang sedari tadi hanya mengamati.

Tokoh terakhir adalah teman soleha. Tokoh teman Soleha tidak mendapatkan deskripsi fisik khusus. Karakter tokoh digambarkan melalui penjabaran perilaku tokoh. Tokoh teman Soleha memiliki karakter egois dan tak acuh terhadap kondisi temannya. Selain itum tokoh teman Soleha berperan sebagai tokoh tambahan, tokoh sederhana, dan tokoh antagonis. Berikut kutipannya. 
Kata Soleha lagi, temannya itu lebih sering pakai headphone, sejenis alat bantu dengar, agar suara dari luar tidak. mengganggu. Kalau sudah begitu, Soleha hanya bisa melihat gambar tanpa memahami kalimat gurunya, seperti melibat ikan emas di akuarium, mangap-mangap tanpa suara.

c. Latar

1) Tempat

Bagian utama cerpen menunjukkan lokasi awal yang akan berkaitan dengan beberapa peristiwa dalam cerita. Dalam cerpen diungkapkan bahwa tokoh bapak tertangkap basah mencuri ponsel di sebuah toko. Namun, tak ada penjelasan lebih lanjut mengenai toko yang dimaksud dalam cerita. Selain itu, bentuk penyampaian latar dan keterangan yang terdapat pada awalan cerita menjadi sebuah informasi langsung atas peristiwa selanjutnya yang akan dihadapi oleh tokoh. Berikut pembuktian mengenai kutipan yang dimaksud dalam cerpen.

Celaka. Mereka tahu aku yang ambil ponsel di toko itu. Hendak lari ke mana ini. Aku tak. tahu karena baru dua kali ini aku ke sini. Yang penting sembunyi saja dulu.

Bagian selanjutnya dalam cerpen ditunjukkan latar tempat berupa jalan. Namun seperti sebelumnya, tidak dijelaskan secara lebih lanjut jalan apakah yang dimaksud pengarang dalam cerita. Berikut pembuktian mengenai kutipan yang dimaksud.

Tapi, ya Tuhan, begitu mendongak ke arah jalan, gerombolan warga datang menyerbu. Dua belas, sembilan belas, waduh, mungkin puluban.

\section{2) Waktu}

Latar waktu dalam cerpen ini diantaranya pagi, bulan, sore, dan malam. Latar waktu pagi hari ditunjukkan pada dialog antar tokoh aku dengan putrinya yang bernama Soleha. Dalam dialog yang diucapkan Soleha, terdapat keterangan waktu yang secara langsung diungkapkan oleh tokoh aku.

Pak, minta tolong beliken HP biar Soleba bisa sekolah. Sudah sebulan lebih ga ikut pelajaran,"

kata Soleha di suatu pagi yang semestinya sejuk. karena saat itu hawa sisa bujan semalam masib enggan pergi.

Selain itu, keterangan latar waktu pagi hari juga terdapat dalam deskripsi keterangan mengenai tokoh Soleha. Dalam cerpen dikatakan bahwa Soleha lahir pada subuh yang tenang, yang mana keterangan tersebut menunjuk pada latar waktu pagi hari.

Soleha labir pada subuh yang tenang. Beberapa saat setelah dia labir, matahari bersinar lembut, seperti ikut memberi selamat.

Latar bulan dalam cerpen ini adalah bulan Agustus. Bulan Agustus dalam cerpen ditunjukkan dalam keterangan keadaan yang sedang dialami oleh tokoh aku saat itu. Keadaan di mana tokoh aku mengungkapkan rasa herannya terhadap perubahan musim di bulan Agustus. Berikut kutipan pembuktian yang terdapat dalam cerpen.

Ini musim yang aneh, bulan Agustus tapi turun bujan. Seaneh kondisi saat ini. Dulu masuke sekolah dilarang bawa HP, sekarang sekolah harus lewat HP.

Penggambaran latar sore hari ditunjukkan dalam monolog yang dilakukan tokoh dengan dirinya sendiri. Berikut kutipan yang terdapat dalam cerpen.

\section{Aku hanya membayangkan wajah Soleha yang baru masuk sekolab menengah pertama. Dia pasti cemas jïka sampai sesore ini ayahnya belum pulang.}

Melalui kutipan tersebut, dapat diketahui bahwa tokoh aku memikirkan anaknya yang mungkin akan mencemaskan dirinya jika sampai waktu sesore itu belum juga kembali ke rumah.

Seperti penggambaran latar sore hari, penggambaran latar malam hari juga tergambar dalam monolog yang dilakukan tokoh dengan dirinya sendiri. Hal tersebut dapat dilihat dalam kutipan di bawah ini.

Dia pasti cemas karena malam ini bakal gagal lagi mengerjakan tugas-tugas sekolahnya karena tidak punya HP.

Melalui kutipan tersebut, diketahui bahwa tokoh aku mencemaskan anaknya yang kembali gagal mengerjakan tugas sekolah saat malam hari.

3) Sudut Pandang 
Sudut pandang yang digunakan dalam cerpen Seorang Ayah yang mencemaskan Mimpinya merupakan sudut pandang orang pertama pelaku utama. Hal tersebut dapat dilihat melalui cara penyebutan "aku" yang digunakan oleh tokoh untuk menyatakan dirinya sebagai pelaku utama dalam cerita. Selain itu, diketahui pula bahwa "aku" sebagai pelaku utama dalam sudut pandang berusaha menceritakan segala peristiwa dan tingkah laku yang dialaminya. Hal tersebut dapat dilihat melalui kutipan di bawah ini.

\section{Aku mengambil beberapa langkah mundur sebagai ancang-ancang melompat. Ketika kaki sudah dua jengkal meninggalkan bumi, sepasang tangan kekar menarik kerah bajuku dari belakang dan mengempasku ke tanah.}

Dari hasil analisi data terhadap cerpen dalam portal berita online Jawa Pos edisi November 2020, diperoleh temuan bahwa cerpen-cerpen yang dimuat tersebut mengandung unsur intrinsik yang berfungsi sebagai pondasi utama dalam terbentuknya sebuah cerita. Hasil ini sesuai dengan penelitian-penelitian yang dilakukan oleh Maryanti et al (2018) dalam cerpen "Katastropa", penelitian Nurcahyati et al(2019) dalam cerpen "Senyum Karyamin", penelitian Surbakti et al (2018) dalam Cerpen "Hening di Ujung Senja", dan penelitian Ujang terhadap Cerpen "Pengemis Dan Shalawat Badar". Dalam cerpen dalam portal berita online Jawa Pos edisi November 2020, diketahui bahwa tiap cerpen yang dimuat memiliki karakteristik tersendiri sehingga menjadikan cerpen satu dengan yang lainnya memiliki keindahan masing-masing.

2. Relevansi Cerpen dalam Portal Berita Online Jawa Pos Edisi November dan Desember 2020 sebagai Materi Ajar Sastra di SMA

Dalam kurikulum 2013, kegiatan pembelajaran sastra dilakukan bersamaan dengan kegiatan pembelajaran bahasa. Kegiatan pembelajaran bahasa (dan sastra) di sekolah memiliki beberapa tujuan yang telah termuat dalam kurikulum. Hal tersebut berkaitan dengan isi Depdikbud (dalam Warsiman, 2017) bahwa tujuan dari pembelajaran sastra di sekolah yaitu untuk mengembangkan kepribadian, memperkaya wawasan, dan menambah pengetahuan serta kompetensi berbahasa seseorang.

Namun dewasa ini, kegiatan pembelajaran sastra di sekolah telah jauh membawa peserta didik ke dalam berbagai kegiatan yang cenderung membosankan. Hal tersebut yang akhirnya memunculkan rasa tidak tertarik peserta didik terhadap kegiatan pembelajaran sastra. Pembelajaran sastra yang hanya bertumpu pada kegiatan menghafal, mencatat, dan mencari hal-hal terkait dengan karya sastra pada akhirnya menjadikan kegiatan pembelajaran kurang relevan. Dalam permasalahan tersebut, keterlibatan guru dalam pengembangan materi ajar sangat diperlukan. Guru sebagai tenaga pendidik dapat memanfaatkan kemudahan dan kemajuan teknologi dalam pengembangan materi ajar. Pemanfaatan tersebut dapat diterapkan pada materi pembelajaran apresiasi sastra di kelas.

Seperti yang diketahui bahwa sebagian besar kegiatan apresiasi sastra di kelas banyak melibatkan peserta didik dengan teks sastra. Namun, sangat disayangkan bahwa sebagian teks sastra yang digunakan oleh guru sebagai rujukan dalam penyampaian materi ajar kurang memadai. Misalnya kegiatan pembelajaran sastra yang hanya mengandalkan buku paket sebagai pedoman belajar atau pemilihan teks sastra yang tidak tepat sasaran.

Permasalahan-permasalahan tersebut dapat ditangani dengan memanfaatkan kemajuan teknologi sebagai alternatif dalam kegiatan pembelajaran. Salah satunya dengan menggunakan teks cerpen dalam portal berita online Jawa Pos sebagai materi pembelajaran sastra di kelas. Beberapa teks cerpen dalam portal berita online Jawa Pos dapat dijadikan sebagai referensi dalam kegiatan pembelajaran sastra khususnya pada kelas XI SMA. Dalam silabus mata pelajaran Bahasa Indonesia kelas XI SMA termuat KD 3.9 dengan isi menganalisis unsur-unsur pembangun cerita pendek dalam buku kumpulan cerita pendek. Beberapa cerpen, khususnya kelima cerpen pada edisi November dan Desember 2020 dapat digunakan sebagai referensi bahan ajar karena di dalamnya terdapat kesesuaian dengan kompetensi dasar dan materi pembelajaran yang termuat dalam silabus.

Cerpen-cerpen tersebut dapat digunakan sebagai materi pembelajaran pada KD 3.9 yang berkaitan dengan pembahasan unsur-unsur pembangun cerpen serta kaidah kebahasaan yang terdapat dalam cerpen. Adanya hubungan kelima cerpen dengan muatan materi pembelajaran pada KD 3.9 maka diharapkan peserta 
didik dapat memahami gaya bahasa berupa pemajasan dalam cerpen. Selain itu melalui beberapa kesesuaian yang terdapat pada kelima cerpen dengan kompetensi dasar dalam silabus, diharapkan dapat menjadi pertimbangan sebagai materi ajar di SMA kelas XI.

\section{KESIMPULAN}

Berdasarkan hasil analisis yang telah dilakukan, diketahui bahwa cerpen-cerpen yang terdapat dalam portal berita online Jawa Pos edisi November dan Desember 2020 mengandung unsur intrinsik yang berfungsi sebagai pondasi utama dalam terbentuknya sebuah cerita. Tiap cerpen yang dimuat memiliki karakteristik tersendiri sehingga menjadikan cerpen satu dengan yang lainnya memiliki keindahan masing-masing. Isi cerpen yang mudah dipahami serta keberagaman tema yang terdapat dalam cerpen, menjadikan kelima cerpen tersebut dapat digunakan sebagai refernsi dalam kegiatan penyampaian materi ajar sastra di SMA kelas XI yang merujuk pada kompetensi dasar 3.9, yaitu menganalisis unsur-unsur pembangun cerita pendek dalam buku kumpulan cerita pendek.

\section{DAFTAR PUSTAKA}

Anonim. (2017). Nielsen: Jawa Pos Koran No 1 Indonesia. [Online]. Tersedia: https://www.pressreader.com/indonesia/jawa-pos/20171207/281496456617467

Cahyono, A. S. (2016). Pengaruh media sosial terhadap perubahan sosial masyarakat di Indonesia. Jurnal Publiciana, 9(1), 140-157.

Gasong, D. (2019). Apresiasi Sastra Indonesia. Yogyakarta: Deepublish.

Ismayani, R. M. (2017). Kreativitas dalam pembelajaran literasi teks sastra. Semantik, 2(2), 67-86.

Maryanti, D., Sujiana, R., \& Wikanengsih, W. (2018). Menganalisis unsur intrinsik cerpen "katastropa" karya han gagas sebagai upaya menyediakan bahan ajar menulis teks cerpen. Parole (Jurnal Pendidikan Bahasa dan Sastra Indonesia), 1(5), 787-792.

Nugrahani, F. (2014). Metode Penelitian Kualitatif dalam Penelitian Pendidikan Bahasa. Solo: Cakra Books

Nurcahyati, D., Yulianti, A., \& Abdurrokhman, D. (2019). Analisis Unsur-Unsur Intrinsik Cerpen "Senyum Karyamin" Karya Ahmad Tohari. Parole (Jurnal Pendidikan Babasa dan Sastra Indonesia), 2(6), 979-986.

Ratna, K. N. (2010). Metodologi Penelitian: Kajian Budaya dan Ilmu Sosial Humaniora pada Umumnya. Yogyakarta: Pustaka Pelajar

Saputra, N. (2020). Pembentukan nilai pendidikan karakter melalui pembelajaran bahasa dan sastra indonesia di sekolah dasar. Prosiding Konferensi Ilmiah Dasar, 2, 388-398.

Saputri, N. (2017). Proses Aktualisasi Diri Tokoh Utama Dalam Novel 9 Summers 10 Autumns Karya Iwan Setyawan. Dialektologi, 2(2), 132-159.

Sarmianti, S. (2017). Guru dalam Cerpen "Bintang-bintang Jasa Cikgu Musa, Ba" dan "Guru Dungu". Madah, 4(1), 1-10.

Sukada, M. (2017). Pembinaan Kritik Sastra Indonesia. Bandung: Angkasa.

Surbakti, F. E., Ramadani, R., \& Heriani, U. (2018). Analisis Unsur Intrinsik Cerpen "Hening Di Ujung Senja" Karya Wilson Nadeak. Asas: Jurnal Sastra, 10(2).

Ujang, U. A. (2021). Analisis Unsur Intrinsik Cerpen "Pengemis Dan Shalawat Badar" Karya Ahmad Tohari. Parole (Jurnal Pendidikan Bahasa dan Sastra Indonesia), 4(3).

Warsiman. (2017). Pengantar Pembelajaran Sastra: Sajian dan Kajian Hasil Riset. Malang: UB Press.

Wicaksono, A. (2017). Pengkajian Prosa Fiksi. Yogyakarta: Garudhawaca. 